University of Wollongong

Research Online

Faculty of Science - Papers (Archive)

Faculty of Science, Medicine and Health

2010

\title{
Response of coral reefs to climate change: expansion and demise of the southernmost Pacific coral reef
}

\author{
Colin D. Woodroffe \\ University of Wollongong, colin@uow.edu.au \\ Brendan P. Brooke \\ Michelle Linklater \\ David M. Kennedy \\ Brian G. Jones \\ University of Wollongong, briangj@uow.edu.au
}

See next page for additional authors

Follow this and additional works at: https://ro.uow.edu.au/scipapers

Part of the Life Sciences Commons, Physical Sciences and Mathematics Commons, and the Social and Behavioral Sciences Commons

\section{Recommended Citation}

Woodroffe, Colin D.; Brooke, Brendan P.; Linklater, Michelle; Kennedy, David M.; Jones, Brian G.; Buchanan, Cameron; Mleczko, Richard; Hua, Quan; and Zhao, Jian-xin: Response of coral reefs to climate change: expansion and demise of the southernmost Pacific coral reef 2010, 1-6.

https://ro.uow.edu.au/scipapers/503

Research Online is the open access institutional repository for the University of Wollongong. For further information contact the UOW Library: research-pubs@uow.edu.au 


\title{
Response of coral reefs to climate change: expansion and demise of the southernmost Pacific coral reef
}

\begin{abstract}
Coral reefs track sea level and are particularly sensitive to changes in climate. Reefs are threatened by global warming, with many experiencing increased coral bleaching. Warmer sea surface temperatures might enable reef expansion into mid latitudes. Here we report multibeam sonar and coring that reveal an extensive relict coral reef around Lord Howe Island, which is fringed by the southernmost reef in the Pacific Ocean. The relict reef, in water depths of 25-50 m, flourished in early Holocene and covered an area more than 20 times larger than the modern reef. Radiocarbon and uranium-series dating indicates that corals grew between 9000 and 7000 years ago. The reef was subsequently drowned, and backstepped to its modern limited extent. This relict reef, with localised re-establishment of corals in the past three millennia, could become a substrate for reef expansion in response to warmer temperatures, anticipated later this century and beyond, if corals are able to recolonise its surface. Citation: Woodroffe, C. D., B. P. Brooke, M. Linklater, D. M. Kennedy, B. G. Jones, C. Buchanan, R. Mleczko, Q. Hua, and J. Zhao (2010), Response of coral reefs to climate change: Expansion and demise of the southernmost Pacific coral reef, Geophys. Res. Lett., 37, L15602, doi: 10.1029/2010GL044067.
\end{abstract}

\section{Keywords}

response, reef, coral, pacific, reefs, climate, change, expansion, demise, southernmost, GeoQUEST

\section{Disciplines}

Life Sciences | Physical Sciences and Mathematics | Social and Behavioral Sciences

\section{Publication Details}

Woodroffe, C. D., Brooke, B. P., Linklater, M., Kennedy, D. M., Jones, B. G., Buchanan, C., Mleczko, R., Hua, Q. \& Zhao, J. (2010). Response of coral reefs to climate change: expansion and demise of the southernmost Pacific coral reef. Geophysical Research Letters, 37 (15), 1-6.

\section{Authors}

Colin D. Woodroffe, Brendan P. Brooke, Michelle Linklater, David M. Kennedy, Brian G. Jones, Cameron

Buchanan, Richard Mleczko, Quan Hua, and Jian-xin Zhao 


\title{
Response of coral reefs to climate change: Expansion and demise of the southernmost Pacific coral reef
}

\author{
Colin D. Woodroffe, ${ }^{1}$ Brendan P. Brooke, ${ }^{2}$ Michelle Linklater, ${ }^{1}$ David M. Kennedy, ${ }^{3}$ \\ Brian G. Jones, ${ }^{1}$ Cameron Buchanan, ${ }^{2}$ Richard Mleczko, ${ }^{2}$ Quan Hua, ${ }^{4}$ and Jian-xin $\mathrm{Zhao}^{5}$ \\ Received 21 May 2010; revised 20 June 2010; accepted 6 July 2010; published 3 August 2010.
}

[1] Coral reefs track sea level and are particularly sensitive to changes in climate. Reefs are threatened by global warming, with many experiencing increased coral bleaching. Warmer sea surface temperatures might enable reef expansion into mid latitudes. Here we report multibeam sonar and coring that reveal an extensive relict coral reef around Lord Howe Island, which is fringed by the southernmost reef in the Pacific Ocean. The relict reef, in water depths of 25-50 m, flourished in early Holocene and covered an area more than 20 times larger than the modern reef. Radiocarbon and uranium-series dating indicates that corals grew between 9000 and 7000 years ago. The reef was subsequently drowned, and backstepped to its modern limited extent. This relict reef, with localised re-establishment of corals in the past three millennia, could become a substrate for reef expansion in response to warmer temperatures, anticipated later this century and beyond, if corals are able to recolonise its surface. Citation: Woodroffe, C. D., B. P. Brooke, M. Linklater, D. M. Kennedy, B. G. Jones, C. Buchanan, R. Mleczko, Q. Hua, and J. Zhao (2010), Response of coral reefs to climate change: Expansion and demise of the southernmost Pacific coral reef, Geophys. Res. Lett., 37, L15602, doi:10.1029/2010GL044067.

\section{Introduction}

[2] Coral reefs occur in shallow water with sea surface temperatures (SST) greater than $18^{\circ} \mathrm{C}$, extending beyond the tropics where warm currents enable establishment [Hopley et al., 2007]. The southernmost reef in the Pacific Ocean fringes $6 \mathrm{~km}$ on the western margin of Lord Howe Island $\left(31^{\circ} 30^{\prime} \mathrm{S}\right)$, with isolated reef patches to north and east. The island is a Miocene volcanic remnant on the western flank of the Lord Howe Rise (foundered continental crust). Basaltic cliffs rise to $875 \mathrm{~m}$, flanked by Quaternary eolianites [McDougall et al., 1981]. The reefs support 50-60 scleractinian coral species, whose rates of growth are only slightly slower than in more tropical locations [Harriott and Banks, 2002]. However, carbonate sediments with temperate biota,

\footnotetext{
${ }^{1}$ School of Earth and Environmental Sciences, University of Wollongong, Wollongong, New South Wales, Australia.

${ }^{2}$ Geoscience Australia, Canberra, ACT, Australia.

${ }^{3}$ School of Geography, Environment and Earth Sciences, Victoria University of Wellington, Wellington, New Zealand.

${ }^{4}$ Australian Nuclear Science and Technology Organization, Kirrawee, New South Wales, Australia.

${ }^{5}$ Radiogenic Isotope Facility, Centre for Microscopy and Microanalysis, University of Queensland, Brisbane, Queensland, Australia.

such as foraminifera and algal rhodoliths, dominate the surrounding shelf [Kennedy et al., 2002]. A broad ridge-like feature, rising from water depths of 30-50 m, is prominent in mid shelf and represents a relict coral reef that formerly encircled the island [Woodroffe et al., 2005, 2006]. We describe sonar swath mapping to determine the extent of the reef, and coring and dating that establishes its age and demise.

\section{Methods}

[3] Seabed topography was determined by sonar mapping using a Kongsberg Simrad EM $30030 \mathrm{kHz}$ multibeam echo sounder aboard $R V$ Southern Surveyor in 2008 (voyage SS06). The sonar frequency of the system is $30 \mathrm{kHz}$, with signal resolved into 135 beams, corrected for vessel heave, roll and pitch. Vertical resolution is $\pm 0.2 \mathrm{~m}$, with horizontal resolution of $\pm 5 \mathrm{~m}$. High resolution data were acquired over the entire relict reef, but were supplemented with singlebeam echosounder, and Laser Airborne Depth Sounder (LADS), data across the lagoon and the Admiralty Islands to the northeast, where the vessel could not be operated. Bottom sediments were examined using a Smith-Macintyre grab sampler and a Topas PS18 parametric $1.5 \mathrm{kHz}$ acoustic sub-bottom profiler [Brooke et al., 2010].

[4] Composition of the relict reef was determined from short cores of $75 \mathrm{~mm}$ diameter recovered using a submersible rock drill lowered from the research vessel. The deepest core penetrated $2.72 \mathrm{~m}$ into reef limestone, with $1.2 \mathrm{~m}$ recovery. Samples of faviid coral and mollusc were selected for accelerator mass-spectrometry (AMS) radiocarbon dating at the Australian Nuclear Science and Technology Organisation (ANSTO) with a precision of $0.5-0.6 \%$. Samples were cleaned, oven-dried, hydrolysed to $\mathrm{CO}_{2}$, and then converted to graphite using the $\mathrm{H}_{2} / \mathrm{Fe}$ method [Hua et al., 2001]. Thermal ionisation mass-spectrometry (TIMS) uraniumseries dating of older samples at the University of Queensland followed analytical procedures described by Zhao et al. [2001], except that a known ${ }^{236} \mathrm{U} /{ }^{233} \mathrm{U}$ ratio in $\mathrm{a}^{229} \mathrm{Th}^{-23} \mathrm{U}^{236} \mathrm{U}$ mixed spike was used for mass fractionation correction. ${ }^{234} \mathrm{U} /{ }^{238} \mathrm{U}$ and ${ }^{230} \mathrm{Th} /{ }^{238} \mathrm{U}$ activity ratios of samples were normalised and ages calculated using halflives of 75,380 years $\left({ }^{230} \mathrm{Th}\right)$ and 244,600 years $\left({ }^{234} \mathrm{U}\right)$. Mineralogy of samples was established by X-ray diffraction. All those submitted for AMS dating were $>98 \%$ aragonite. Traces of calcite were detected in some material used for TIMS analysis, but only those with $>92 \%$ aragonite were dated. Initial ${ }^{234} \mathrm{U} /{ }^{238} \mathrm{U}$ values of samples are close to those of seawater and pristine coral, and their ${ }^{230} \mathrm{Th}$ ages are not significantly affected by this minor diagenesis. Paired TIMS and AMS ages for two samples enabled determination 


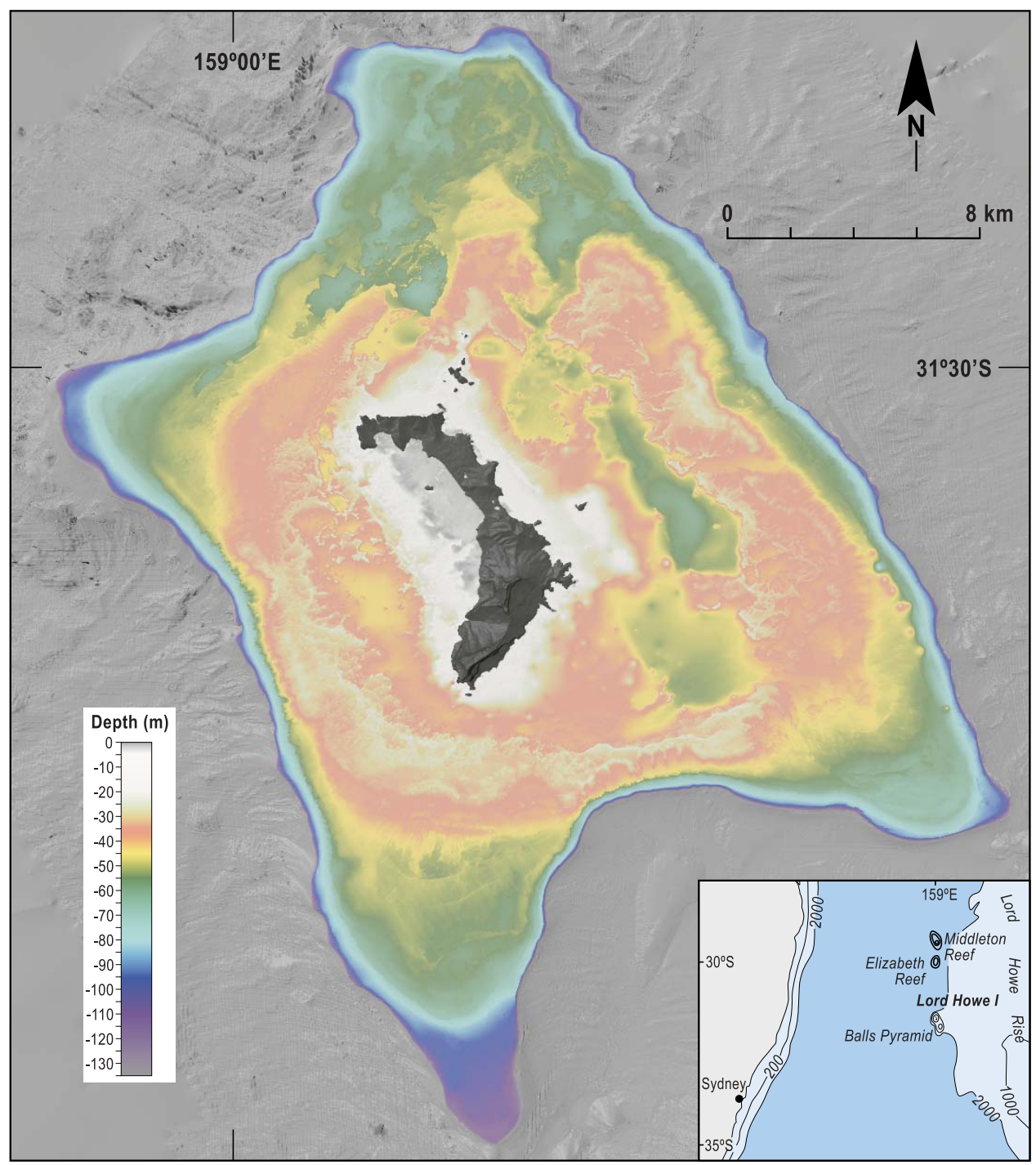

Figure 1. Digital terrain model of the shelf around Lord Howe Island, showing the relict reef compiled from multibeam sonar supplemented inshore by other data sources [see Brooke et al., 2010].

of a $\Delta \mathrm{R}$ value of $-11 \pm 39$ yrs used to calibrate radiocarbon ages (with Marine04 data using CALIB 5.01), and TIMS and AMS ages are reported in years prior to $1950 \mathrm{AD}$ (cal BP).

\section{Relict Reef Morphology}

[5] Figure 1 shows 3-dimensional morphology around Lord Howe Island, mapping the relict reef based on multibeam sonar. The shelf around Lord Howe Island comprises three zones: outer shelf (55-70 m water depth); relict reef (rising from $50 \mathrm{~m}$ depth with an upper surface, encrusted by coralline algae at $24-40 \mathrm{~m}$ depth); and inner shelf $(\sim 40-50 \mathrm{~m}$ depth, with sandy substrate and sedimentary reflectors in sub-bottom profiling). The reef ranges between 0.5 and $5.8 \mathrm{~km}$ wide; it lies close to land to the northeast, but its steep inner flank lies $>6 \mathrm{~km}$ offshore to the east. It has an area of at least $145 \mathrm{~km}^{2}$, covering $28 \%$ of the shelf. Three former reef passages dissect north, northeast and eastern margins, and prominent spur and groove features indicate the southern margin was exposed to considerable wave energy.

\section{Stratigraphy and Chronology of Relict Reef}

[6] Six rotary drill cores were recovered from water depths of 24 to $34 \mathrm{~m}$ (Figure 2), penetrating almost $3 \mathrm{~m}$ into the relict reef, with variable recovery. Cores contain corals and molluscs, in a matrix of coralline algae. Visual description of cores 13,14, 21 and 22 indicated reddishbrown discoloration, micritization, borings and cavities in the lower sections characteristic of interglacial limestone. However, TIMS and AMS dates indicate that the major phase of growth was early Holocene (Tables 1 and 2). A hiatus in reef growth occurred during mid-Holocene in several cores, with some late Holocene re-establishment of coral, especially at site 15 (34 m water depth).

[7] The extensive relict reef underwent significant vertical accretion during the early Holocene. A TIMS age of $9079 \pm$ 52 cal yrs BP on coral in core 22, from a depth of almost 

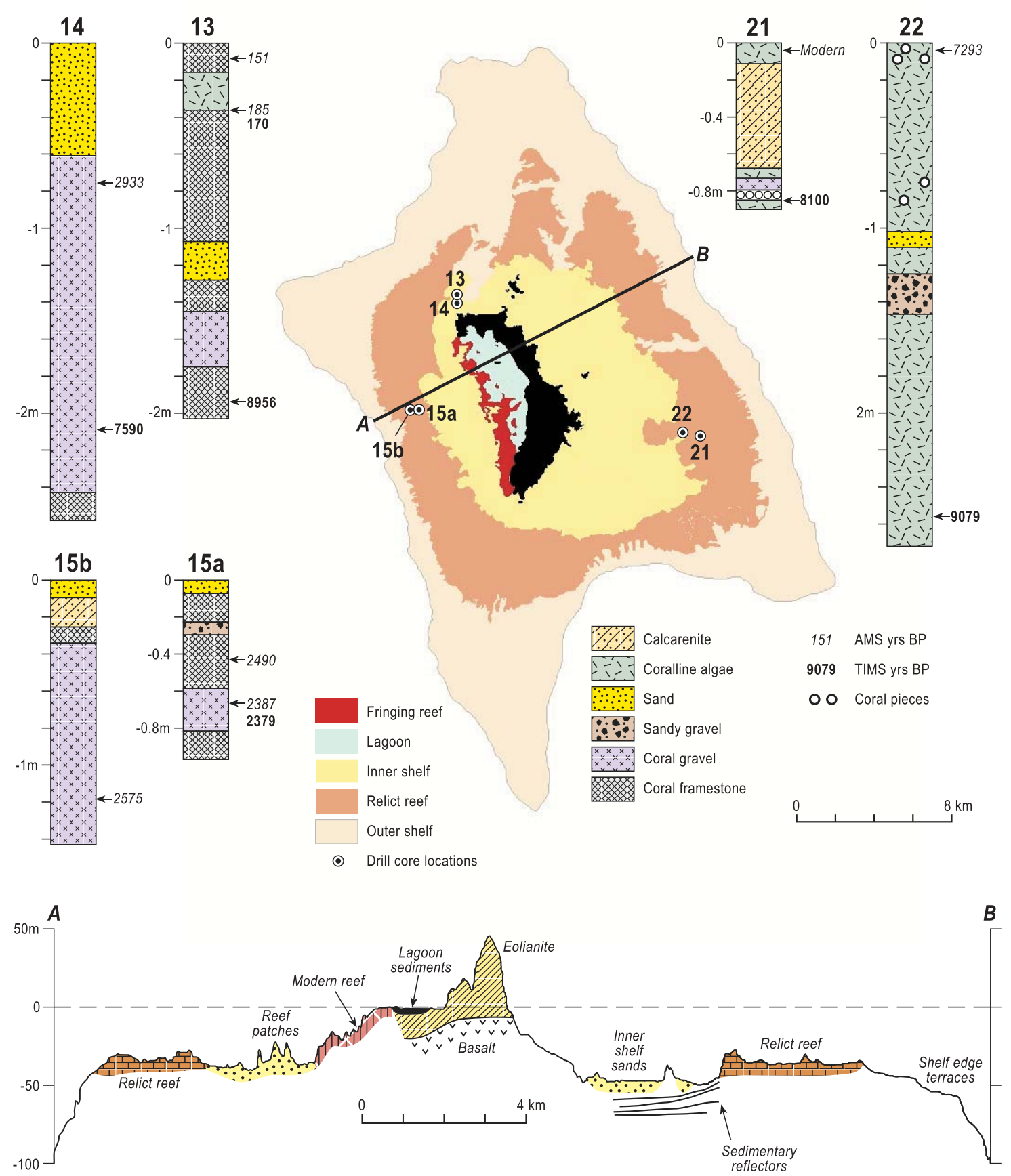

Figure 2. Distribution of relict and modern reef around Lord Howe Island and location, stratigraphy, and chronology of cores. The schematic cross-section (A-B) shows the relict reef and the location to which it backstepped on the west of the island, forming the modern reef and lagoon.

$3 \mathrm{~m}$ below the surface, and AMS age at the surface almost two millennia younger (7169-7407 cal yrs BP) indicates that the upper part of the reef accreted at an average vertical rate of $1.5 \mathrm{~mm} / \mathrm{yr}$ until growth ceased around 7000 years ago (Figure 2). A similar phase of early Holocene accretion preceding reef demise is implied by a basal date in core 21; the upper part of this core contained a modern
Tridacna clam, indicating that the relict reef still forms substrate for some benthic organisms. On the western and northern margins of Lord Howe Island, the early Holocene age for the reef is substantiated by dates from cores 13 and 14; however, more recent reef growth (around $2400 \mathrm{cal}$ yrs $\mathrm{BP})$, occurred at site 15. 
Table 1. AMS Dating of Core Samples ${ }^{\mathrm{a}}$

\begin{tabular}{|c|c|c|c|c|c|c|c|c|c|c|c|}
\hline \multirow[b]{3}{*}{ Sample } & \multirow[b]{3}{*}{ Lab Code } & \multirow{3}{*}{$\begin{array}{l}\text { Sample Depth } \\
(\mathrm{cm})\end{array}$} & \multirow[b]{3}{*}{ Material } & \multirow{3}{*}{$\begin{array}{r}\delta^{13} \mathrm{C} \\
(\% 0)\end{array}$} & \multirow{3}{*}{$\begin{array}{c}{ }^{14} \mathrm{C} \text { Age } \\
(\mathrm{yr} \mathrm{BP}) \pm 1 \sigma\end{array}$} & \multirow{3}{*}{$\begin{array}{c}\text { Th Age } \\
(\text { cal BP } \pm 2 \sigma)\end{array}$} & \multicolumn{5}{|c|}{ Calibrated ${ }^{14} \mathrm{C}$ age (cal BP) } \\
\hline & & & & & & & \multicolumn{2}{|c|}{$1 \sigma$} & \multicolumn{2}{|c|}{$2 \sigma$} & \multirow{2}{*}{$\begin{array}{c}\text { Median Calibrated } \\
\text { Age }^{\mathrm{c}}\end{array}$} \\
\hline & & & & & & & Lower & Upper & Lower & Upper & \\
\hline 13RDC01 a-6 & OZL208 & $\mathrm{R}=6 ; \mathrm{I}=22$ & Coral & 0.3 & $510 \pm 40$ & $\mathrm{n} / \mathrm{a}$ & 87 & 244 & 0 & 260 & $151(0-260)$ \\
\hline 13RDC01 b-16 & OZL209 & $R=16 ; I=40$ & Coral & -0.2 & $545 \pm 35$ & $170 \pm 2$ & 132 & 262 & 0 & 291 & $185(0-291)$ \\
\hline 14RDC01 a-17 & OZL210 & $\mathrm{R}=17 ; \mathrm{I}=62$ & $\begin{array}{c}\text { Mollusc } \\
\text { Operculum }\end{array}$ & 3.4 & $3135 \pm 50$ & $\mathrm{n} / \mathrm{a}$ & 2842 & 3017 & 2768 & 3111 & $2933(2768-3111)$ \\
\hline 15RDC01 a-27 & OZL211 & $\mathrm{R}=27 ; \mathrm{I}=23$ & Coral & -0.3 & $2750 \pm 45$ & $\mathrm{n} / \mathrm{a}$ & 2363 & 2572 & 2336 & 2669 & $2490(2336-2669)$ \\
\hline 15RDC01 c-40 & OZL212 & $\mathrm{R}=40 ; \mathrm{I}=60$ & Coral & -1.3 & $2670 \pm 45$ & $2379 \pm 13$ & 2305 & 2457 & 2225 & 2605 & $2387(2225-2605)$ \\
\hline 15RDC02 -32 & OZL213 & $\mathrm{R}=32 ; \mathrm{I}=120$ & Coral & 0.5 & $2815 \pm 40$ & $\mathrm{n} / \mathrm{a}$ & 2499 & 2678 & 2390 & 2717 & $2575(2390-2717)$ \\
\hline 21RDC01 a-2 & OZL214 & $\mathrm{R}=2 ; \mathrm{I}=8$ & $\begin{array}{c}\text { Clam shell } \\
\text { Genus Tridacna }\end{array}$ & 1.9 & $430 \pm 40$ & $\mathrm{n} / \mathrm{a}$ & - & - & - & - & Modern \\
\hline 22RDC01 b-9 & OZL215 & $\mathrm{R}=9 ; \mathrm{I}=10$ & Coral & -0.5 & $6750 \pm 50$ & $\mathrm{n} / \mathrm{a}$ & 7235 & 7364 & 7169 & 7407 & 7293 (7169-7407) \\
\hline
\end{tabular}

${ }^{\text {a Calibrated }}{ }^{14} \mathrm{C}$ ages reported in years prior to $1950 \mathrm{AD}$.

${ }^{\mathrm{b}} \mathrm{R}$, Recovered; I, Interpreted.

${ }^{\mathrm{c}}$ Values in parentheses are $2 \sigma$.

[8] The relict reef was immense $(>20$ times the area of modern reefs), but it was drowned prior to establishment of the modern reef. Upright branches of Acropora encountered in vibrocores 4-6 m beneath the lagoon floor and dated around 7000 cal yrs BP [Kennedy and Woodroffe, 2000] indicate that the modern reef formed at a similar time to other Indo-Pacific reefs (which established over antecedent topography at around $10-25 \mathrm{~m}$ depth around $8000 \mathrm{cal} \mathrm{yrs}$ BP [see Harris et al., 2008, Table 3]). However, this midlate Holocene reef growth, associated with stabilization of sea level close to present, was preceded at Lord Howe Island by a much more extensive phase of early Holocene reef establishment which flourished for 2000 years, before being drowned as the reef backstepped to its modern foundations (see cross-section A-B in Figure 2).

\section{Drowning by Sea-Level Rise and Reef Demise}

[9] This relict reef is particularly significant for several reasons. First, it demonstrates that reefs were much more extensive 9000 years ago than they are at present at this latitudinal limit to reef growth. This is contrary to the view that reef distribution contracted during glaciations and were slow to recolonise mid-latitude seas that were marginal for corals [Daly, 1934]. Second, a phase of reef establishment occurred across the shelf flanking Lord Howe Island prior to, and in water depths deeper than, the foundations of most modern reefs, presumably because a broad shelf provided suitable substrate at this depth. Third, this reef, at the southern limit to reef development, was drowned during the early Holocene, extending into the Holocene the record of episodes of reef drowning documented for the late Pleistocene [Beaman et al., 2008].

[10] Figure 3 shows postglacial sea-level rise, and an envelope within which reef growth was considered possible in the southwest Pacific [Andréfouët et al., 2009]. Around $9000 \mathrm{cal}$ yrs BP, there was a barrier reef around Lord Howe Island, at or close to sea level. The reef accreted at rates insufficient to keep pace with sea-level rise and had drowned by 7000 cal yrs BP. Its demise may have been accelerated by an abrupt sea-level rise [Blanchon and Shaw, 1995]. Independent evidence for a sea-level jump in early Holocene has recently been described from southeast Asia [Bird et al., 2007; Hori and Saito, 2007; Tamura et al.,
2009], the Baltic Sea [Yu et al., 2007], and the eastern USA [Cronin et al., 2007], perhaps associated with rapid melt of the Laurentide Icesheet [Carlson et al., 2008]. Shelfedge reefs are common throughout the Caribbean [Hubbard et al., 2008], and backstepped to modern reef locations 7000-6500 years ago. Complex early Holocene shelf reefs flourished 9000-7000 years ago in southeast Florida, at the northern latitudinal limit to reef growth, ceasing growth before 6000 cal yrs BP [Toscano and Lundberg, 1998; Banks et al., 2008]. The demise of some shelf-edge reefs has been attributed to environmental degradation associated with sedimentation or eutrophication as the adjacent shelf was flooded, rather than abrupt sea-level rise [Toscano and Macintyre, 2003]. This interpretation seems less likely for the mid-shelf Lord Howe reefs as there are not horizontal substrates that would have been inundated at elevations coincident with the surface of the relict reef. Around Lord Howe Island, some reef growth occurred during late Holocene when sea level was at its present level, implying potential for recolonization of the relict reef when environmental conditions are favourable. Human activities have imposed stresses, such as eutrophication, pollution and sedimentation, which impede expansion of reefs in many parts of the world. Protection of marine environments around this World Heritage site is intended to minimise these additional stresses. However, the extent to which the relict reef may be able to support vigorous coral communities in future will depend on a range of environmental factors, as it is now in water depths that are largely beyond those optimal for coral growth.

\section{Conclusion}

[11] Evidence that coral reefs extended beyond their present latitudinal limits during the Holocene and previous interglacials [Veron, 1992; Greenstein and Pandolfi, 2008], is significant as human-induced climate change impacts tropical reefs [Precht and Aronson, 2004]. Deeper water $(>10 \mathrm{~m})$ reefs and non-framework corals on shelves, such as the Lord Howe shelf, may represent important refugia from increases in SST [Riegl and Piller, 2003]. We demonstrate that an enormous early Holocene reef flourished around Lord Howe Island, and that it was drowned with 


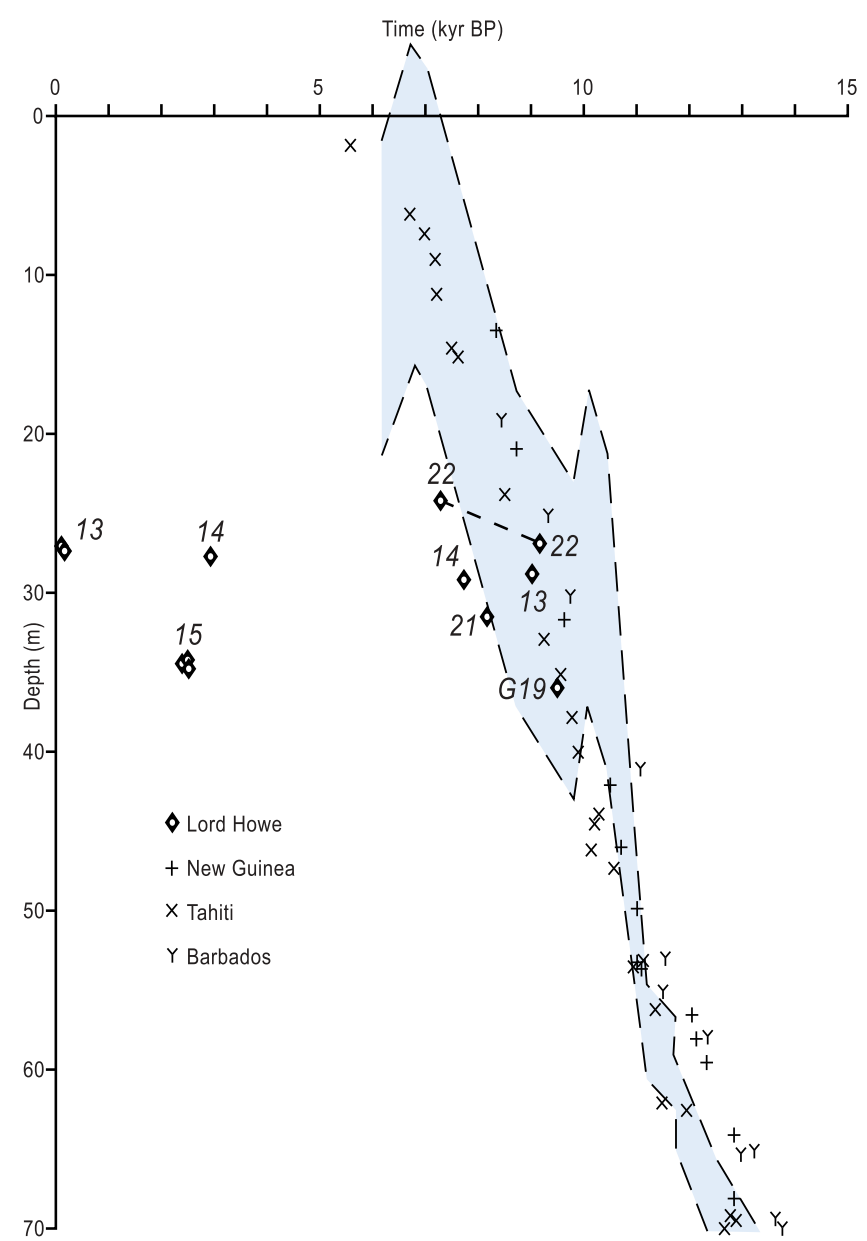

Figure 3. Age-depth plot of dated coral samples recovered from the relict reef (G19 is fossil branching coral recovered in grab sampler from $36 \mathrm{~m}$ water depth [see Kennedy et al., 2002]), plotted in comparison with sea-level curves reconstructed for the early Holocene and an envelope within which coral growth is considered possible for the southwest Pacific. (Following Andréfouët et al. [2009]: Barbados data based on Fairbanks [1989] sampling as reported in the work of Bard et al. [1990]. Tahiti data are from Bard et al. [1996], and New Guinea Huon Peninsula data are from Chappell and Polach [1991] and Edwards et al. [1993]. The sealevel envelope represents upper and lower limits to the depth range in which living coral can grow as inferred from a rapidly uplifting island, Urélapa Island, southern Vanuatu, (average uplift 3mm/year) after Cabioch et al. [2003].)

reef growth backstepping to its modern position. This new record from the southern Pacific indicates the complex interaction of environmental processes that control coral reef growth.

[12] Acknowledgments. We are grateful to the Marine National Facility, captain and crew of $R V$ Southern Surveyor, and Geoscience Australia (GA) technical staff for field support. This research was partly funded by the Commonwealth Environment Research Facilities (CERF) program as a component of the Marine Biodiversity Hub, and AMS dating was supported by AINSE. B.P.B., R.M., and C.B. publish with permission of the CEO of GA. 


\section{References}

Andréfouët, S., G. Cabioch, B. Flamand, and B. Pelletier (2009), A reappraisal of the diversity of geomorphological and genetic processes of New Caledonian coral reefs: A synthesis from optical remote sensing, coring and acoustic multibeam observations, Coral Reefs, 28, 691-707, doi:10.1007/s00338-009-0503-y.

Banks, K. W., B. M. Riegl, V. P. Richards, B. K. Walker, K. P. Helme, L. K. B. Jordan, J. Phipps, M. S. Shivji, R. E. Speiler, and R. E. Dodge (2008), The reef tract of continental southeast Florida (Miami-Dade, Broward and Palm Beach counties, USA), in Coral Reefs of the USA, edited by B. M. Riegl and R. E. Dodge, pp. 175-220, Springer, Dordrecht, Netherlands, doi:10.1007/978-1-4020-6847-8 5.

Bard, E., B. Hamelin, R. G. Fairbanks, and A. Zindler (1990), Calibration of the $14 \mathrm{C}$ timescale over the past 30,000 years using mass spectrometric U-Th ages from Barbados corals, Nature, 345, 405-410.

Bard, E., B. Hamelin, M. Arnold, L. Montaggioni, G. Cabioch, G. Faure, and F. Rougerie (1996), Deglacial sea-level record from Tahiti corals and the timing of global meltwater discharge, Nature, 382, 241-244, doi: $10.1038 / 382241 \mathrm{a} 0$

Beaman, R. J., J. M. Webster, and R. J. A. Wust (2008), New evidence for drowned shelf edge reefs in the Great Barrier Reef, Australia, Mar. Geol., 247, 17-34, doi:10.1016/j.margeo.2007.08.001.

Bird, M. I., L. K. Fifield, T. S. Teh, C. H. Chang, N. Shirlaw, and K. Lambeck (2007), An inflection in the rate of early mid-Holocene eustatic sea-level rise: A new sea-level curve from Singapore, Estuarine Coastal Shelf Sci., 71, 523-536, doi:10.1016/j.ecss.2006.07.004

Blanchon, P., and J. Shaw (1995), Reef drowning during the last deglaciation: Evidence for catastrophic sea-level rise and ice-sheet collapse, Geology, 23, 4-8, doi:10.1130/0091-7613(1995)023<0004: RDDTLD $>2.3 . C O ; 2$.

Brooke, B. P., et al. (2010), Geomorphology of the Lord Howe Island shelf and submarine volcano: SS06-2008 post-survey report, Geosci. Aust. Rec., in press.

Cabioch, G., A. Banks-Cutler, W. J. Beck, G. S. Burr, T. Corriège, R. L. Edwards, and F. W. Taylor (2003), Continuous reef growth during the last 23 cal kyr BP in a tectonically active zone (Vanuatu, South West Pacific), Quat. Sci. Rev., 22, 1771-1786, doi:10.1016/S0277-3791(03) 00170-7

Carlson, A. E., A. N. Legrande, D. W. Oppo, R. E. Came, G. A. Schmidt, F. S. Anslow, L. M. Licciardi, and E. A. Obbink (2008), Rapid early Holocene deglaciation of the Laurentide ice sheet, Nat. Geosci., I, 620-624, doi:10.1038/ngeo285.

Chappell, J., and H. Polach (1991), Post glacial sea level rise from a coral record at Huon Peninsula, Papua New Guinea, Nature, 349, 147-149, doi:10.1038/349147a0

Cronin, T. M., P. R. Vogt, D. A. Willard, R. Thunnell, J. Halka, M. Berke, and J. Pohlman (2007), Rapid sea level rise and ice sheet response to 8,200-year climate event, Geophys. Res. Lett., 34, L20603, doi:10.1029/2007GL031318.

Daly, R. A. (1934), The Changing World of the Ice Age, Yale Univ. Press, New Haven, Conn.

Edwards, R. L., W. J. Beck, G. S. Burr, D. J. Donahue, J. M. A. Chappell, A. L. Bloom, E. R. M. Druffel, and F. W. Taylor (1993), A large drop in atmospheric ${ }^{14} \mathrm{C} /{ }^{12} \mathrm{C}$ and reduced melting in the Younger Dryas, documented with ${ }^{230} \mathrm{Th}$ ages of corals, Science, 260, 962-968, doi:10.1126/ science. 260.5110 .962

Fairbanks, R. G. (1989), A 17,000-year glacio-eustatic sea level record: influence of glacial melting rates on the Younger Dryas event and deep-ocean circulation, Nature, 342, 637-642, doi:10.1038/342637a0.

Greenstein, B. J., and J. M. Pandolfi (2008), Escaping the heat: Range shifts of reef coral taxa in coastal Western Australia, Global Change Biol., 14, 513-528, doi:10.1111/j.1365-2486.2007.01506.x.

Harriott, V. J., and S. A. Banks (2002), Latitudinal variation in coral communities in eastern Australia, Coral Reefs, 21, 83-94.

Harris, P. T., A. D. Heap, J. F. Marshall, and M. McCulloch (2008), A new coral reef province in the Gulf of Carpentaria, Australia: Colonization, growth and submergence during the early Holocene, Mar. Geol., 251, 85-97, doi:10.1016/j.margeo.2008.02.010.

Hopley, D., S. G. Smithers, and K. Parnell (2007), Geomorphology of the Great Barrier Reef: Development, Diversity and Change, Cambridge Univ. Press, Cambridge, U. K., doi:10.1017/CBO9780511535543.
Hori, K., and Y. Saito (2007), An early Holocene sea-level jump and delta initiation, Geophys. Res. Lett., 34, L18401, doi:10.1029/2007GL031029.

Hua, Q., G. E. Jacobsen, U. Zoppu, E. M. Lawson, A. A. Williams, A. M. Smith, and M. J. McGann (2001), Progress in radiocarbon target preparation at the Antares AMS Centre, Radiocarbon, 43, 275-282.

Hubbard, D. K., R. B. Burke, I. P. Gill, W. R. Ramirez, and C. Sherman (2008), Coral-reef geology: Puerto Rico and the US Virgin Islands, in Coral Reefs of the USA, edited by B. M. Riegl and R. E. Dodge, pp. 263-302, Springer, Dordrecht, Netherlands, doi:10.1007/978-14020-6847-8 7 .

Kennedy, D. M., and C. D. Woodroffe (2000), Holocene lagoonal sedimentation at the latitudinal limits of reef growth, Lord Howe Island, Tasman Sea, Mar. Geol., 169, 287-304, doi:10.1016/S0025-3227(00)00093-1.

Kennedy, D. M., C. D. Woodroffe, B. G. Jones, M. E. Dickson, and C. V. G. Phipps (2002), Carbonate sedimentation on subtropical shelves around Lord Howe Island and Balls Pyramid, southwest Pacific, Mar. Geol., 188, 333-349, doi:10.1016/S0025-3227(02)00406-1.

McDougall, I., B. J. J. Embleton, and D. B. Stone (1981), Origin and evolution of Lord Howe Island, southwest Pacific Ocean, J. Geol. Soc. Aust., $28,155-176$.

Precht, W. F. and R. B. Aronson (2004), Climate flickers and range shifts of coral reefs, Front. Ecol. Environ., 2, 307-314, doi:10.1890/1540-9295 (2004)002[0307:CFARSO]2.0.CO;2.

Riegl, B., and W. E. Piller (2003), Possible refugia for reefs in times of environmental stress, Int. J. Earth Sci., 92, 520-531, doi:10.1007/ s00531-003-0328-9.

Tamura, T., Y. Saito, S. Sieng, B. Ben, M. Kong, I. Sim, S. Choup, and F. Akiba (2009), Initiation of the Mekong River delta at 8 ka: Evidence from the sedimentary succession in the Cambodian lowland, Quat. Sci. Rev., 28, 327-344, doi:10.1016/j.quascirev.2008.10.010.

Toscano, M. A., and J. Lundberg (1998), Early Holocene sea-level record from submerged fossil reefs on the southeast Florida margin, Geology, 26, 255-258, doi:10.1130/0091-7613(1998)026<0255:EHSLRF $>2.3$. $\mathrm{CO} ; 2$.

Toscano, M. A., and I. G. Macintyre (2003), Corrected western Atlantic sea-level curve for the last 11,000 years based on calibrated ${ }^{14} \mathrm{C}$ dates from Acropora palmata framework and intertidal mangrove peat, Coral Reefs, 22, 257-270, doi:10.1007/s00338-003-0315-4.

Veron, J. E. N. (1992), Environmental control of Holocene changes to the world's most northern hermatypic coral outcrop, Pac. Sci., 46, 405-425.

Woodroffe, C. D., M. E. Dickson, B. P. Brooke, and D. M. Kennedy (2005), Episodes of reef growth at Lord Howe Island, the southernmost reef in the southwest Pacific, Global Planet. Change, 49, 222-237, doi:10.1016/j.gloplacha.2005.09.003.

Woodroffe, C. D., D. M. Kennedy, B. P. Brooke, and M. E. Dickson (2006), Geomorphological evolution of Lord Howe Island and carbonate production at the latitudinal limit to reef growth, J. Coastal Res., 22, 188-201, doi:10.2112/05A-0014.1.

Yu, S.-Y., B. E. Berglund, and P. Sandgren (2007), Evidence for a rapid sea-level rise 7600 yr ago, Geology, 35, 891-894, doi:10.1130/ G23859A.1

Zhao, J. X., Q. K. Xia, and K. D. Collerson (2001), Timing and duration of the last interglacial inferred from high resolution U-series chronology of stalagmite growth in Southern Hemisphere, Earth Planet. Sci. Lett., 184, 635-644, doi:10.1016/S0012-821X(00)00353-8.

B. P. Brooke, C. Buchanan, and R. Mleczko, Geoscience Australia, GPO Box 378, Canberra, ACT 2601, Australia.

Q. Hua, Australian Nuclear Science and Technology Organisation, Locked Bag 2001, Kirrawee, NSW 2232, Australia.

B. G. Jones, M. Linklater, and C. D. Woodroffe, School of Earth and Environmental Sciences, University of Wollongong, Wollongong, NSW 2522, Australia.

D. M. Kennedy, School of Geography, Environment and Earth Sciences, Victoria University of Wellington, PO Box 600, Wellington 6140, New Zealand.

J. Zhao, Radiogenic Isotope Facility, Centre for Microscopy and Microanalysis, University of Queensland, Brisbane, Qld 4072, Australia. 